\title{
Two weather radar time series of the altitude of the volcanic plume during the May 2011 eruption of Grímsvötn, Iceland
}

\author{
G. N. Petersen, H. Bjornsson, P. Arason, and S. von Löwis \\ Icelandic Meteorological Office, Reykjavík, Iceland \\ Correspondence to: G. N. Petersen (gnp@vedur.is)

\begin{abstract}
Received: 28 March 2012 - Published in Earth Syst. Sci. Data Discuss.: 3 May 2012
\end{abstract} \\ Revised: 13 September 2012 - Accepted: 17 September 2012 - Published: 18 October 2012
}

\begin{abstract}
The eruption of Grímsvötn volcano in Iceland in 2011 lasted for a week, 21-28 May. The eruption was explosive and peaked during the first hours, with the eruption plume reaching $20-25 \mathrm{~km}$ altitude. The height of the plume was monitored every $5 \mathrm{~min}$ with a C-band weather radar located at Keflavík International Airport and a mobile X-band radar, $257 \mathrm{~km}$ and $75 \mathrm{~km}$ distance from the volcano respectively. In addition, photographs taken during the first half-hour of the eruption give information regarding the initial rise. Time series of the plume-top altitude were constructed from the radar observations. This paper presents the two independent radar time series. The series have been cross validated and there is a good agreement between them. The echo top radar series of the altitude of the volcanic plume are publicly available from the Pangaea Data Publisher (doi:10.1594/PANGAEA.778390).
\end{abstract}

1

An explosive subglacial volcanic eruption started in the Grímsvötn caldera in southern Iceland at, or a few minutes before, 19:00 UTC on 21 May 2011. The volcanic plume from the eruption was monitored using a C-band and an Xband weather radar, located at different distances from the volcano. In addition there were visual observations from the ground and air as well as a number of photographs of the plume. The strength of the eruption decreased rapidly and the plume was at or below $10 \mathrm{~km}$ altitude after $24 \mathrm{~h}$. The eruption was officially declared over on 28 May at 07:00 UTC.

Grímsvötn is Iceland's most active volcano. Previously it has erupted twice in the last $15 \mathrm{yr}$, in December 1998 and November 2004 (Vogfjörd et al., 2005), and has during the past centuries had a frequency close to one eruption per decade. As the volcano is located beneath Vatnajökull icecap, the eruptions are always explosive, with ash and other volcanic material being ejected into the atmosphere. The eruption in May 2011 was of short duration but caused some disruption to aviation in the region. The winds advecting the ash from the crater were mainly northerly and northeasterly.
There were short-time closures of the Keflavík International Airport in Iceland, and airports in northern UK and northern Germany were also affected.

The purpose of this article is to present and describe time series of the altitude of the volcanic plume, as measured by the two weather radars operating during the eruption. While the time series from the C-band radar is continuous from 21 25 May, at a $5 \mathrm{~min}$ time resolution, the time series from the $\mathrm{X}$-band radar is fragmented due to operational difficulties. In addition, a cross validation of the time series is presented. Series of photographs taken during the first half-hour of the eruption give further information of the initial rise of the volcanic plume.

The structure of this paper is as follows: in Sect. 2 we describe the weather radars, their specifications and limitations. There is a short description of the photographs used to describe the rise in the first hour of the eruption in Sect. 3. The time series are presented in Sect. 4 and cross-validated in Sect. 5. Finally, concluding remarks follow in Sect. 6. 
Table 1. Specifications of the mobile weather radar during the eruption of Grímsvötn in 2011.

\begin{tabular}{ll}
\hline Type & X-band Meteor 50DX $(9.4 \mathrm{GHz})$ \\
Duration of operation & 22 May, 04:00 UTC-25 May, 14:00 UTC \\
Location & Kirkjubæjarklaustur, $63^{\circ} 46^{\prime} 30^{\prime \prime} \mathrm{N}, 17^{\circ} 57^{\prime} 49^{\prime \prime} \mathrm{W}$ \\
Antenna type & XDP15, parabolic, prime focus reflector \\
Reflector diameter & $1.8 \mathrm{~m}$ \\
Height of antenna & $47 \mathrm{~m}$ a.s.l. \\
Peak transmitted power & $75 \mathrm{~kW}$ \\
Pulse duration & $2 \mu \mathrm{s}$, but $0.45 \mu$ s on 23 May, $02: 23-12: 45 \mathrm{UTC}$ \\
Wavelength & $3.2 \mathrm{~cm}$ \\
Pulse repetition frequency & $550 \mathrm{~Hz}$, but $1200 \mathrm{~Hz}$ on 23 May $02: 23-12: 45 \mathrm{UTC}$ \\
Operational range & $120 \mathrm{~km}$ \\
Range step & $0.2 \mathrm{~km}$ \\
Minimum gain of antenna & $42.5 \mathrm{~dB}$ \\
Minimum detectable signal & $-113 \mathrm{dBm}$ \\
Duration of reflectivity scans & $20 \mathrm{~s} \mathrm{per} \mathrm{elevation} \mathrm{angle,} \mathrm{but} 15 \mathrm{~s} \mathrm{on} 23 \mathrm{May}, 02: 23-12: 45 \mathrm{UTC}$ \\
Duration of beam raising & $5 \mathrm{~s} \mathrm{per} \mathrm{elevation} \mathrm{angle}$ \\
Half-power beam width & $1.3^{\circ}$ \\
Polarization & Horizontal and vertical \\
Angle position accuracy & $\pm 0.1^{\circ}$ \\
Scanning speed & $3 \mathrm{rpm}$, but 4 rpm on $23 \mathrm{May}, 02: 23-12: 45 \mathrm{UTC}$ \\
Elevation angles reflectivity scans, & $0.7^{\circ}, 1.8^{\circ}, 3.1^{\circ}, 4.6^{\circ}, 6.3^{\circ}, 8.3^{\circ}, 10.6^{\circ}, 13.2^{\circ}$, \\
on 22 May & $16.2^{\circ}, 19.7^{\circ}, 23.8^{\circ}, 28.4^{\circ}, 33.8^{\circ}$ and $40.0^{\circ}$ \\
Elevation angles reflectivity scans, & $0.5^{\circ}, 1.6^{\circ}, 2.9^{\circ}, 4.4^{\circ}, 6.1^{\circ}, 8.1^{\circ}, 10.4^{\circ}, 13.1^{\circ}$, \\
from 23 May & $16.1^{\circ}, 19.6^{\circ}, 23.7^{\circ}, 28.4^{\circ}, 33.8^{\circ}$ and $40.0^{\circ}$ \\
Reflectivity threshold (echo top) & $-20 \mathrm{dBZ}$ \\
Data managing software & Rainbow ${ }^{\circledR} 5$ \\
\hline
\end{tabular}

\section{The weather radars: specifications and limitations}

\subsection{The Keflavík radar}

The weather radar at Keflavík International Airport in southwest Iceland was the only fixed-position operational weather radar in Iceland during the eruption. It is owned and operated by the Icelandic Meteorological Office (IMO). Its specifications are described in detail in Arason et al. (2011); see Table 1 of that paper, but here specifications pertinent to data from the Grímsvötn 2011 eruption are briefly summarised. The radar is an Ericsson C-band doppler radar located about $3 \mathrm{~km}$ north of the airport and $257 \mathrm{~km}$ from the Grímsvötn volcano (Fig. 1). Its main purpose is weather monitoring and the radar detects precipitation and precipitating clouds within a maximum range of $480 \mathrm{~km}$, but the operational strategy is to make $240 \mathrm{~km}$ reflectivity scans and $120 \mathrm{~km}$ doppler scans. Each scan is made four times an hour. Previously, the radar has been successfully used for monitoring six volcanic eruptions in Iceland (Larsen et al., 1992; Lacasse et al., 2004; Vogfjörd et al., 2005; Oddsson, 2007; Arason et al., 2011; Petersen et al., 2012). Radars have also been used to monitor eruptions in the US and Italy (Harris and Rose, 1983; Rose et al., 1995; Gouhier and Donnadieu, 2008). See also Bull and Buumann (2012) and references therein. In case of a volcanic eruption in Iceland within a radius of $240-480 \mathrm{~km}$ from the radar, the strategy is to make $480 \mathrm{~km}$ reflectivity

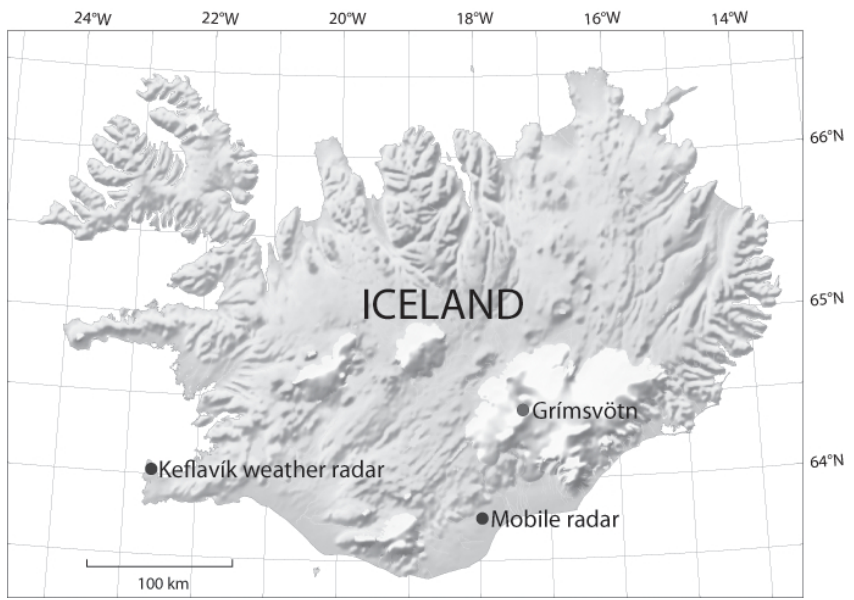

Figure 1. A map of Iceland and the location of the stationary weather radar at Keflavík airport and the mobile weather radar in Kirkjubæjarklaustur. The radars were 257 and $75 \mathrm{~km}$ from Grímsvötn volcano, respectively.

scans every $5 \mathrm{~min}$. During the Grímsvötn 2011 eruption, the first $480 \mathrm{~km}$ reflectivity scan was made at 19:48 UTC on 21 May. No doppler scans were made during the eruption period.

The half-power beam width is $0.9^{\circ}$ and during scans the beam circles from an initial angle of $0.5^{\circ}$, increasing the 

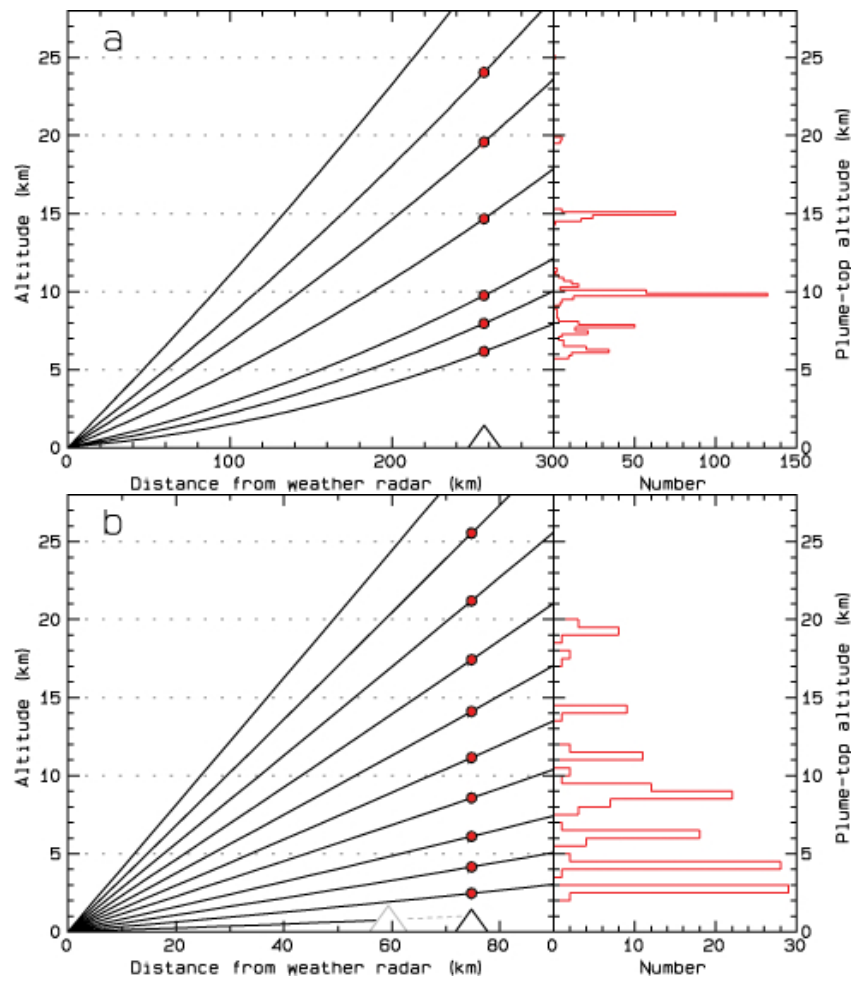

Figure 2. Left: a range-height diagram of the altitude (km a.s.1.) as a function of distance from the weather radars $(\mathrm{km})$, for the lowest elevation angles of the scanning strategy during the eruption. The location of Grímsvötn is marked with a black triangle. Right: a histogram of the plume-top altitudes (km a.s.l.) observed by the radars. (a) Range-height diagram and histogram of altitude estimates from the C-band Keflavík weather radar. The seven lowest elevation angles $\left(0.5-6.0^{\circ}\right)$ are shown. (b) Range-height diagram and histogram of altitude estimates from the X-band mobile weather radar located close to Kirkjubæjarklaustur. The eleven lowest elevation angles $\left(0.5-23.8^{\circ}\right)$ are shown. Note that the lowest elevation angle is blocked by the Pórðarhyrna mountain, marked by a gray triangle.

elevation angle at the end of each circle to a maximum angle of $40^{\circ}$ (Arason et al., 2011). This means that over Grímsvötn the beam width is $5.8 \mathrm{~km}$ and the altitude of the lowest beam is $6.2 \mathrm{~km}$ a.s.l. The partial beam blockage of the lowest elevation angle $\left(0.5^{\circ}\right)$ in the direction of Grímsvötn has been estimated to be below $20 \%$, using a 1-km digital elevation model (Crochet, 2009). The radar has therefore a fairly clear view of the eruption plume, as can be seen in Fig. 2a which shows the seven lowest elevation angles of the current scanning strategy and their height above sea level for a distance of up to $300 \mathrm{~km}$. The half-power beam width of $0.9^{\circ}$ results in an overlapping of the beams for the three lowest elevation angles, $0.5^{\circ}, 0.9^{\circ}$ and $1.3^{\circ}$.

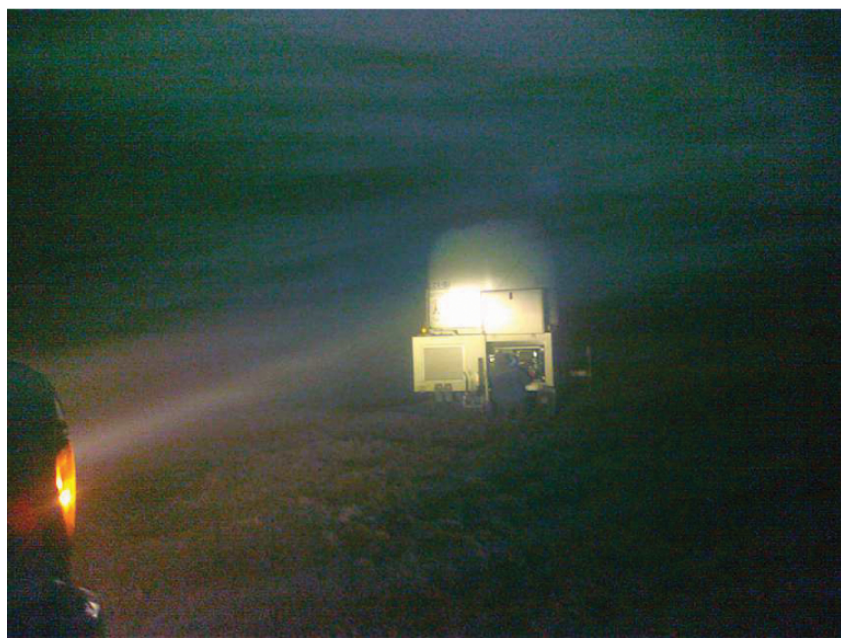

Figure 3. The X-band mobile radar during very difficult operating conditions. Intense ash-fall caused very low visibility and darkness. Photo Geirfinnur S. Sigurðsson, 22 May 2011 at 09 UTC.

\subsection{The mobile radar}

During the eruption a mobile X-band radar was operated in southern Iceland. X-band radars operate at a shorter wavelength than C-band radars and are therefore more sensitive to smaller particles. Higher resolution volume data could potentially give information about the concentration and size distribution of particles, which is important for downstream dispersion analysis and forecasts. Further research on the volume reflectivity data is ongoing but is outside of the scope of this paper. Furthermore X-band radars are small, can be portable and run on diesel engine power. The X-band radar operating in Iceland in 2011 is a Meteor 50DX radar (Selex Systems Integration $\mathrm{GmbH}$ ) on loan from the Italian Civil Protection until IMO had its own mobile radar up and running in spring 2012. The radar is a compact weather radar on a trailer, with a total weight of $2800 \mathrm{~kg}$, which makes it easy to move to favourable locations in case of an eruption. Table 1 contains specifications of the radar for operations during the eruption of Grímsvötn in 2011. The mobile radar was up and running in Kirkjubæjarklaustur, southern Iceland (Fig. 1), at 03:27 UTC, 22 May or about $8.5 \mathrm{~h}$ after the eruption started. It was moved $500 \mathrm{~m}$ eastward, and $200 \mathrm{~m}$ closer to the volcano, between 17:00 and 18:00 UTC on 24 May to a location where it could be connected to mains power.

Kirkjubæjarklaustur is located south of the volcano, in a region that experienced heavy ash fall. This resulted in extremely challenging environment for operating the radar. There were intermittent power generation problems during the first two days, while powered with a diesel engine, and difficult working conditions. Figure 3 shows a photograph of the mobile radar, taken in the field on 22 May at about 09 UTC when ash fall obscured all daylight. The problems with discontinuous power generation meant that the radar 
Table 2. Elevation angles and altitudes (km a.s.l.) of the radar-beam midpoints at the lowest levels over Grímsvötn volcano.

\begin{tabular}{|c|c|c|c|c|c|c|c|c|c|c|}
\hline \multicolumn{11}{|l|}{ Keflavík radar } \\
\hline Elevation angles $\left({ }^{\circ}\right)$ & & & & 0.5 & 0.9 & 1.3 & 2.4 & & 3.5 & 4.5 \\
\hline Altitude (km) & & & & 6.2 & 8.0 & 9.9 & 14.9 & & 19.9 & 24.4 \\
\hline Mobile radar & \multicolumn{10}{|c|}{22 May 2011} \\
\hline Elevation angles $\left({ }^{\circ}\right)$ & $0.7^{*}$ & 1.8 & 3.1 & 4.6 & 6.3 & 8.3 & 10.6 & 13.2 & 16.2 & 19.7 \\
\hline Altitude (km) & 1.3 & 2.7 & 4.4 & 6.4 & 8.6 & 11.2 & 14.2 & 17.5 & 21.3 & 25.6 \\
\hline Mobile radar & \multicolumn{10}{|c|}{ 23-25 May 2011} \\
\hline Elevation angles $\left({ }^{\circ}\right)$ & $0.5^{*}$ & 1.6 & 2.9 & 4.4 & 6.1 & 8.1 & 10.4 & 13.1 & 16.1 & 19.6 \\
\hline Altitude (km) & 1.0 & 2.5 & 4.2 & 6.1 & 8.3 & 10.9 & 13.9 & 17.3 & 21.1 & 25.4 \\
\hline
\end{tabular}

* Note that the lowest elevation angle of the mobile radar was orographically blocked in the direction of Grímsvötn volcano.

needed to be restarted a few times and this resulted unintentionally in slightly different scanning strategy on 22 May than from 23 May and onward (see Tables 1 and 2). However, as the strength of the eruption decreased rapidly, elevation angles $6.3-13.3^{\circ}$ detected the plume-top on 22 May but elevation angles $1.6-6.1^{\circ}$ from 23 May. Also, the altitude difference over Grímsvötn between the two sets of elevation angles is $300 \mathrm{~m}$ or less. Given the beam half-power width of $1.3^{\circ}$, or $1.7 \mathrm{~km}$ over Grímsvötn, we do not expect this difference to affect the results.

The view of the eruption site from Kirkjubæjarklaustur is obscured by Pórðarhyrna mountain (1668 m a.s.l.). As a result the lowest elevation angle beam $\left(0.5^{\circ}\right.$ from 23 May) is orographically blocked and the second lowest angle beam $\left(1.6^{\circ}\right)$ is estimated to be $40 \%$ blocked.

Figure $2 b$ shows the 11 lowest elevation angles of the scanning strategy during the eruption and their height above sea level for a distance of up to $90 \mathrm{~km}$. Note that due to the halfpower beam width of $1.3^{\circ}$ the three lowest elevation angles, $0.5^{\circ}, 1.6^{\circ}$ and $2.9^{\circ}$, overlap.

\subsection{A comparison of the vertical detection limitations of the two radars}

Table 2 shows a comparison of the altitudes of the lowest elevation angles of both radars. The volcanic plume rose to about $25 \mathrm{~km}$ in the initial phase of the eruption, but the maximum observed height after the mobile radar started operating was $20 \mathrm{~km}$ a.s.l. As described previously the lowest angle $\left(0.5^{\circ}\right)$ of the mobile radar was orographically blocked, but the next eight elevation angles spanned the range of plume altitudes from 2.5 to $21.1 \mathrm{~km}$ a.s.l. and were sufficient to monitor the progress of the eruption. In contrast, due to the distance from the C-band radar to Grímsvötn the lowest level that the Keflavík radar could detect the plume was at $6.2 \mathrm{~km}$ and the six lowest elevation angles were sufficient to cover the range of plume altitudes observed during the eruption.

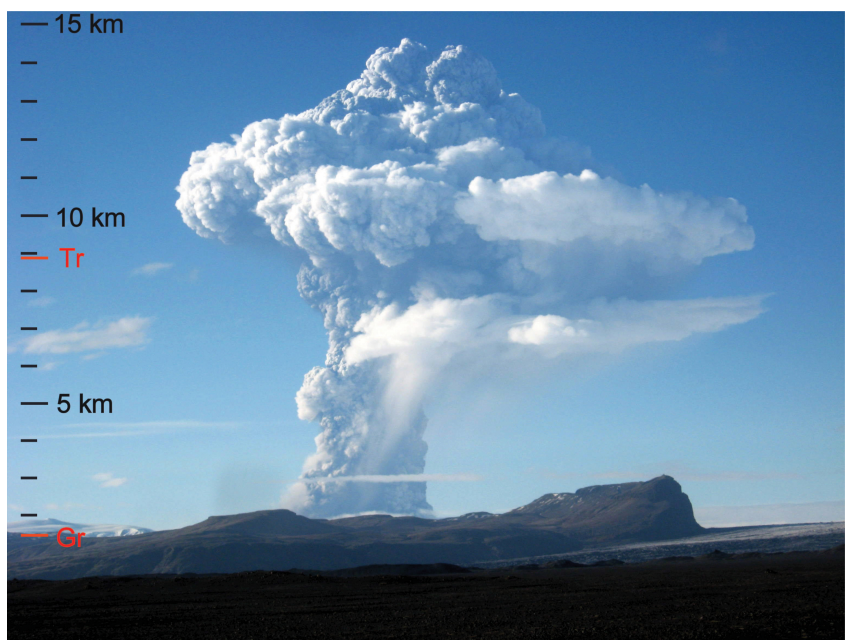

Figure 4. The initial Grímsvötn eruption plume seen from Skeiðarársandur, $50 \mathrm{~km}$ south of the volcano. Approximate altitude scale at the distance of Grímsvötn $(\mathrm{Gr})$ on the left, and the tropopause $(\mathrm{Tr})$ at this time was at about $8.9 \mathrm{~km}$. Photo Bolli Valgarðsson, 21 May 2011 at 19:20 UTC.

\section{Photographs}

The sky was clear over Grímsvötn when the eruption started in the early evening of 21 May. Several photographs were taken during the first half-hour of the eruption. Of particular interest is a series of photographs taken from Skeiðarársandur, $50 \mathrm{~km}$ south of Grímsvötn, for which we have been able to estimate a height scale. The first photo of the plume at 19:09 UTC shows the plume reaching about $6 \mathrm{~km}$ in altitude. From that and the subsequent photos, the rise speed of the plume head is estimated as $10-25 \mathrm{~m} \mathrm{~s}^{-1}$.

Figure 4 shows one of these photos, taken by Bolli Valgarðsson at 19:20 UTC, when the plume had reached over $14 \mathrm{~km}$ a.s.l. That evening the tropopause was observed at $8.9 \mathrm{~km}$ altitude at Keflavík airport, and Fig. 4 shows clearly 


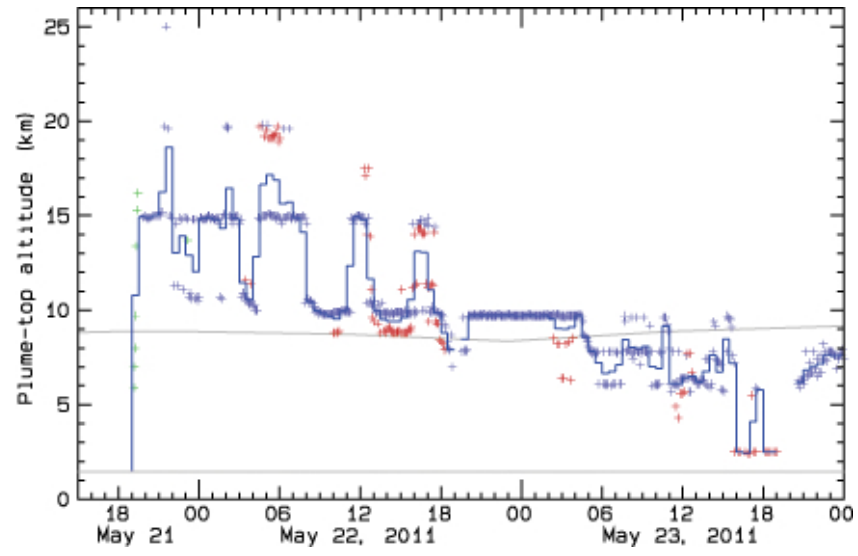

Figure 5. The time series of the 5-min detected plume-top altitude (km a.s.l.) during the first $53 \mathrm{~h}$ of the eruption. Altitude estimates are from the C-band weather radar (blue) and the X-band mobile radar (red), as well as the initial rise of the plume estimated from photographs (green). The altitude of the tropopause, observed by Keflavík radiosondes is shown at about $9 \mathrm{~km}$ a.s.l. (gray). The lower gray line represents the altitude of the Grímsvötn caldera. A 30-min average plume-top altitude of all the estimates is shown by the blue curve.

how the plume spread horizontally when it entered the very stable air of the stratosphere.

\section{The time series}

Two time series have been constructed, from the detected echo tops of each radar. The echo top height is defined from the highest altitude where the threshold reflectivity is exceeded. A linear interpolation of the reflectivity value of the highest beam exceeding the threshold and the reflectivity value of the beam above are used to estimate the echo top height (see Arason et al., 2011 for details).

The threshold reflectivity applied for both radars was set to $-20 \mathrm{dBZ}$. The minimum detectable signal (MDS) of the C-band and the X-band radars is $-109 \mathrm{dBm}$ and $-113 \mathrm{dBm}$, corresponding to a signal at the volcano of $+2 \mathrm{dBZ}$ and $-10 \mathrm{dBZ}$, respectively. With hindsight the threshold value is too low. However, we have verified that this choice of $-20 \mathrm{dBZ}$ does not affect the estimates of the echo top heights generated by the radar software.

Figure 5 shows the two radar time series during the first $53 \mathrm{~h}$ of the eruption as well as the initial rise of the plume estimated from photographs. The Keflavík radar was set to scan within $480 \mathrm{~km}$ radius from 19:48 UTC, and the first detection of the eruption plume is therefore after the initial rise with echo top height of $14.9 \mathrm{~km}$ a.s.l. The mobile radar became operational at 03:27 UTC on 22 May detecting the echo top at $11.7 \mathrm{~km}$. As can be seen from Fig. 5, the availability of the data from the Keflavík radar is much higher than from the mobile radar, due to previously mentioned challenging operations of the mobile radar.

Due to the semi-discrete stepping of the radar detection of the plume top altitude, it can be difficult to get a clear picture of the height variations of the plume from the raw data. Figure 5 also shows a 30-min average of the plume-top altitude based on the echo top heights from both radars as well as estimates of the initial rise from photographs. The figure shows more clearly that the plume-top height had large variations in time, often decreasing/increasing by several $\mathrm{km}$ over a short time period. In fact, the variation in altitude had an oscillation time of about $5 \mathrm{~h}$. This oscillation is also evident in lightning activity and tiltmeter data and is therefore due to eruption variations.

\section{Cross-validation}

To cross-validate the plume-top altitude data series from the two radars, synchronous observations were compared. The Keflavík and the mobile radar series include 587 and 168 values of altitude estimates, respectively. For all the 168 scans of the mobile radar, there exists a corresponding radar scan by the Keflavík radar within at least $2 \mathrm{~min}$. For this comparison $2 \mathrm{~min}$ are considered synchronous. During 66 of these Keflavík scans, the plume was below minimum detection height. The remaining 102 cases of synchronous independent plume-top altitude estimates were used for comparison.

The comparison of these 102 plume-top altitude estimates is summarized in Table 3 and in Fig. 6. As can be seen in the figure, the estimates are concentrated to the semi-discrete altitudes that arise as a result of the discrete elevation angles of the radars. In Table 3 the data are categorized by the elevation angles of the Keflavík radar: $0.5^{\circ}, 0.9^{\circ}, 1.3^{\circ}$ and $2.4^{\circ}$. For each of these four elevation angles, the number of cases, range and mean values are shown for both radars. Furthermore, the mean difference between the altitude estimates is shown along with a standard error. The overall plume-top altitude mean difference between the two radar estimates is not significantly different from zero. The mean difference is about $80 \mathrm{~m}$ with an uncertainty of $\pm 240 \mathrm{~m}$.

A least squares line through the origin gives $y=1.026 x$, with a coefficient of determination $R^{2}=0.67$, when $x$ and $y$ are the plume-top altitude estimates from the Keflavík and the mobile radar, respectively. The slope is not significantly different from unity, and using $y=1 x$ also results in $R^{2}=0.67$.

The two radars, which are of different type and operating at different wavelengths, were located at very different distances from the volcano and with different sets of elevation angles resulting in different vertical resolution of the plume. Despite this the estimated plume-top altitudes are on average not significantly different. 
Table 3. Comparison of synchronous estimates of the plume-top altitude by the two radars. Range and mean values are in km a.s.l.

\begin{tabular}{|c|c|c|c|c|c|c|c|}
\hline \multicolumn{2}{|c|}{ Keflavík clusters } & \multirow[t]{2}{*}{$N$} & \multicolumn{2}{|c|}{ Keflavík radar } & \multicolumn{2}{|c|}{ Mobile radar } & \multirow{2}{*}{$\begin{array}{r}\text { Mean difference } \\
\pm \text { std. error }\end{array}$} \\
\hline Angle & Range & & Range & Mean & Range & Mean & \\
\hline $0.5^{\circ}$ & $<7$ & 12 & $5.7-6.5$ & 6.15 & $2.5-10.3$ & 6.15 & $0.00 \pm 0.52$ \\
\hline $0.9^{\circ}$ & $7-8.5$ & 6 & $7.2-7.9$ & 7.70 & $2.5-7.7$ & 5.53 & $-2.17 \pm 0.69$ \\
\hline $1.3^{\circ}$ & $8.5-12$ & 60 & $9.1-10.7$ & 9.91 & $6.3-14.1$ & 9.64 & $-0.28 \pm 0.23$ \\
\hline $2.4^{\circ}$ & $12-17$ & 24 & $14.4-15.1$ & 14.81 & $9.4-19.7$ & 16.38 & $+1.56 \pm 0.70$ \\
\hline$>2.4^{\circ}$ & $>17$ & 0 & - & - & - & - & - \\
\hline All data & & 102 & $5.7-15.1$ & 10.49 & $2.5-19.7$ & 10.57 & $+0.08 \pm 0.24$ \\
\hline
\end{tabular}

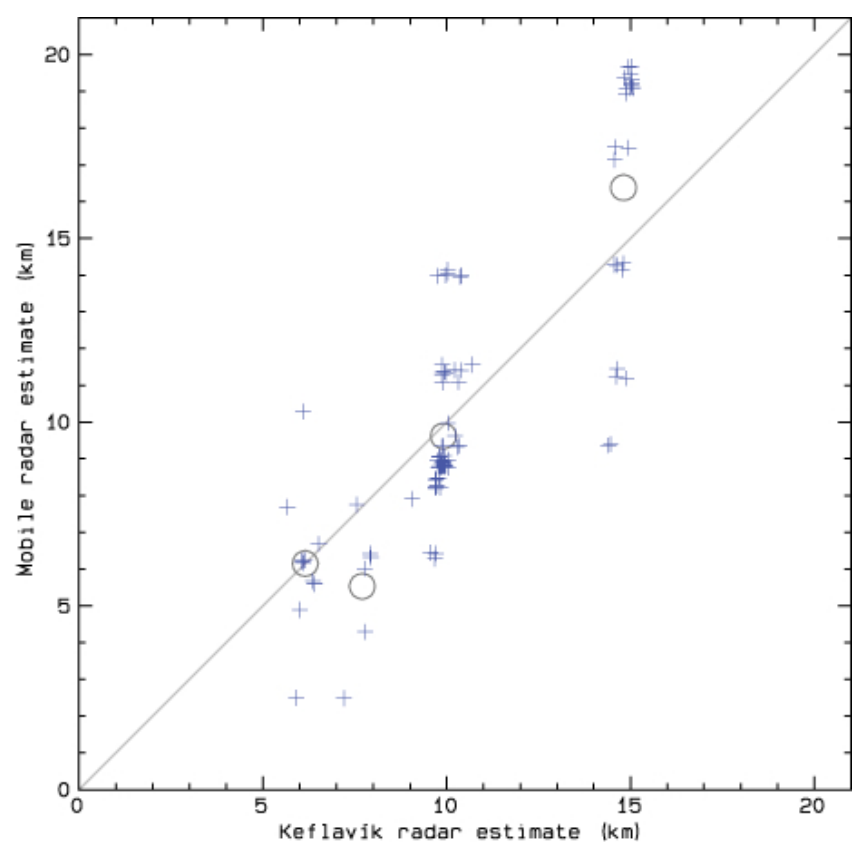

Figure 6. Comparison of synchronous plume-top altitude estimates by the two radars. The circles show mean values of clusters for the Keflavík radar elevation angles (see Table 3).

\section{Conclusions}

Although the eruption of Grímsvötn in May 2011 was of short duration, it still caused some disruptions of air traffic in northern Europe and emphasised the importance of improving monitoring of explosive volcanic plumes as well as of transport and dispersion of ash and other volcanic material in the atmosphere. In fact, a large European project, FUTUREVOLC, starting in autumn 2012 has as one of its goals to develop a monitoring system integrating ground-based and remote sensing observations.

The paper describes two independent time series of the altitude of the volcanic plume during the eruption as observed with a C-band weather radar and an X-band mobile radar located $257 \mathrm{~km}$ and $75 \mathrm{~km}$ from the volcano, respectively. The two time series compare favourably; the C-band series is more complete while the X-band series has slightly higher vertical resolution.

There are gaps in the data from the mobile radar, mainly due to the very difficult operating conditions. Clearly when applying mobile radars for eruption monitoring, it is beneficial to have pre-designated observational locations with the needed infrastructure in place for quick initiation of operation. Locating the radar outside of the thickest ash cloud would ease operations, although that may not always be possible. The difficulties related to the operations of the mobile radar emphasise the need for auxiliary operational systems outside of the affected area, such as the Keflavík radar. Although the vertical resolution of the data is coarser than from a mobile system located closer to the erupting volcano, the operation is stable and the data provide vital information on the eruption. Another C-band radar was installed in eastern Iceland in spring 2012 and all active volcanoes in Iceland are now within a $240 \mathrm{~km}$ distance from a C-band radar. However, it is obvious that for a minor explosive eruption the $\mathrm{C}$-band radars may not be able to detect the volcanic plume due to the distance from the radars, orographic blocking and/or the operating wavelength. Therefore, mobile X-band radars at carefully chosen locations are important. Selection of such sites with regards to all active volcanoes is ongoing in Iceland.

This was the first time a mobile radar was available for volcanic eruption plume monitoring in Iceland, and the eruption was therefore the first real test of its usefulness for this purpose. The data from the radar were very useful; however, it is clear that for future eruptions changing the scanning strategy to increase the vertical resolution may yield improved information on the structure of the plume. Figures 2 and 5 show that, though the mobile radar used eight elevation angles to detect the eruption plume, this results in only a small addition to the vertical resolution given by the Keflavík radar, using six elevation angles for monitoring of the plume. While the main purpose of the Keflavík radar is weather monitoring and therefore the scanning strategy is rather strict, the purpose of the mobile radar is solely volcanic plume monitoring and the scanning strategy is therefore more flexible. Adding elevation angles to the mobile radar scans and subsequently decreasing the time resolution would improve volcanic plume monitoring. In such a scenario the fixed radar would give an 
estimate of the height of the volcanic plume 12 times an hour (every $5 \mathrm{~min}$ ), with an uncertainty of $2-3 \mathrm{~km}$, for eruption of the size and location of the Grímsvötn 2011 eruption, while the mobile radar would 4-6 times an hour supply higher spatial resolution data of the eruption plume. This would result in not only better estimates of the plume altitude but would also give higher resolution volume data.

Acknowledgements. The team operating the mobile radar during the eruption consisted of Geirfinnur S. Sigurðsson, Porgils Ingvarsson and Pórarinn H. Harðarson. In addition we would like to thank Geirfinnur S. Sigurðsson for providing a photograph of the X-band radar in action, and together with Bolli Pálmason for valuable discussions and assistance. The photographs of the initial rise of the plume were provided by Bolli Valgarðsson and Ingólfur Bruun.

Edited by: G. König-Langlo

\section{References}

Arason, P., Petersen, G. N., and Bjornsson, H.: Observations of the altitude of the volcanic plume during the eruption of Eyjafjallajökull, April-May 2010, Earth Syst. Sci. Data, 3, 9-17, doi:10.5194/essd-3-9-2011, 2011.

Bull, K. F. and Buumann, H.: An overview of the 2009 eruption of Redoubt Volcano, Alaska, J. Volcanol. Geotherm. Res., doi:10.1016/j.jvolgeores.2012.06.024, in press, 2012.

Crochet, P.: Enhancing radar estimates of precipitation over complex terrain using information derived from an orographic precipitation model, J. Hydrol., 377, 417-433, doi:10.1016/j.jhydrol.2009.08.038, 2009.

Gouhier, M. and Donnadieu, F.: Mass estimations of ejecta from Strombolian explosions by inversion of Doppler radar measurements, J. Geophys. Res., 113, B10202, doi:10.1029/2007JB005383, 2008.
Harris, D. M. and Rose, W. I.: Estimating particle sizes, concentrations, and total mass of ash in volcanic clouds using weather radar, J. Geophys. Res., 88, 10969-10983, doi:10.1029/JC088iC15p10969, 1983.

Lacasse, C., Karlsdóttir, S., Larsen, G., Soosalu, H., Rose, W. I., and Ernst, G. G. J.: Weather radar observations of the Hekla 2000 eruption cloud, Iceland, Bull. Volcanol., 66, 457-473, doi:10.1007/s00445-003-0329-3, 2004.

Larsen, G., Vilmundardóttir, E., and Porkelsson, B.: Heklugosið 1991: Gjóskufallið og gjóskulagið frá fyrsta degi gossins (The Hekla eruption of 1991 - The tephra fall), Náttúrufræðingurinn, 61, 159-176, 1992.

Oddsson, B.: The Grímsvötn eruption in 2004: Dispersal and total mass of tephra and comparison with plume transport models, Master's thesis, University of Iceland, 2007.

Petersen, G. N., Bjornsson, H., and Arason, P.: The impact of the atmosphere on the Eyjafjallajökull 2010 eruption plume, J. Geophys. Res., 117, D00U07, doi:10.1029/2011JD016762, 2012.

Rose, W. I., Kostinski, A. B., and Kelley, L.: Real-time C-band radar observations of 1992 eruption clouds from Crater Peak, Mount Spurr Volcano, Alaska, in: The 1992 eruptions of Crater Peak vent, Mount Spurr Volcano, Alaska, edited by: Keith, T. E. C., vol. B2139 of U.S. Geological Survey Bulletin, 19-26, U.S. Geological Survey, 1995.

Vogfjörd, K. S., Jakobsdóttir, S. S., Gudmundsson, G. B., Roberts, M. J., Ágústsson, K., Arason, P., Geirsson, H., Karlsdóttir, S., Hjaltadóttir, S., Ólafsdóttir, U., Thorbjarnardóttir, B., Skaftadóttir, T., Sturkell, E., Jónasdóttir, E. B., Hafsteinsson, G., Sveinbjörnsson, H., Stefánsson, R., and Jónsson, T. V.: Forecasting and monitoring a subglacial eruption in Iceland, EOS Trans. AGU., 86, 245-248, doi:10.1029/2005EO260001, 2005. 